\title{
Diversity and genetic potential of various morphological traits among common bean (Phaseolus vulgaris, Fabaceae) landraces
}

\author{
TURA BAREKE \\ Oromia Agricultural Research Institute, Ethiopia. P.O.Box: 81265 Addis Ababa, Ethiopia. Tel.: +251-114707102, Fax.: +251-114707127, \\ email: tura_berake@iqqo.org
}

Manuscript received: 23 July 2019. Revision accepted: 18 October 2019.

\begin{abstract}
Bareke T. 2019. Diversity and genetic potential of various morphological traits among common bean (Phaseolus vulgaris, Fabaceae) landraces. Biodiversitas 20: 3237-3245. The study was undertaken to identify the morphological diversity and genetic potential among landraces of common bean (Phaseolus vulgaris L.) at field conditions of Adama District, Ethiopia. Twenty four common bean landraces from different agroecological zones were collected and grown in three replications. Data of eight agromorphological descriptors were collected using IBPGR protocol. Accordingly, Zale wehy was significantly different $(\mathrm{p}<0.05)$ from all landraces with the highest mean number of pods per plant. On the other hand, the mean number of seeds per pod was significantly $(\mathrm{p}<0.05)$ higher for DobOLE followed by Dima, Kalibushay and Adi tikko while Logoma dume has the lowest number of seeds per pod. The average number of seeds per pod had inverse relationship with seed size. The highest diversity was found in number of seed per plant among landraces while the lowest diversity was found in number of seed per pod. Based on morphological traits similarities among 24 landraces were classified into 4 major categories. Heritability was the highest for seed length (0.97) followed by number of seed per pod (0.94) and seed per plants (0.69) and the lowest $(0.1)$ for height of plant and the rest found between these values. The variability observed in seed length, number of seeds per pod, number of seeds per plant and number of pods per plant which could be utilized in variety improvement programs. Therefore, crop breeders could give emphasis to these traits of landraces to monitor and use for the breeding program, future production and for other domestic purposes.
\end{abstract}

Keywords: Common bean, diversity, landraces, morphological traits, pod, seed

\section{INTRODUCTION}

Landraces are crops with wide genetic diversity, which are known locally, and have not undergone the proper crop improvement (Njoki 2013) and associated with traditional farming systems (Villa et al. 2005). It is a heterogeneous group that evolved in a certain ecogeographical zone and adapted to the edaphic and climatic conditions as well as to the local management regimes and the traditional modes of use (Francesc et al. 2017). Among other things, a landrace is distinguishable by its adaptability to a particular environment, resilience, cultural values and organoleptic properties. Each individual landrace population can be recognized as a sub-group within a named category used by farmers (Benz et al. 2007). Landraces have specific growing requirements and defined agro-environments showing inter and intra-varietal phenotypic variability (Carovic-Stanko et al. 2017).

Some landraces have developed tolerance to particular abiotic and biotic stresses, (Stephen et al. 2013) many of which showing resistance to pathogens, pests and various a biotic stresses (Newton et al. 2009; Bertoldo et al. 2014). They are morphologically distinct in the eyes of farmers who consider a combination of characters that include morphological, growth, food quality as well as ecological adaptation to delimit one from the other (Villa et al. 2005; Lobo et al. 2010).

Wide-ranging shapes of common bean seeds grown in many parts of continent occupy an important part of the diversity of agricultural crops (Ivanovska et al. 2012). The food, agricultural and ecological values of common bean (Phaseolus vulgaris L.) are tremendous (Bareke et al. 2018). It is one of the most important and widely distributed pulses that have the broadest range of genetic resources and its grain used to direct human consumption (Singh 1999; Sperotto and Ricachenevsky 2017). Nutritionally, common bean contains high protein content and micronutrients (iron and folic acid, and complex carbohydrates) and it has been described as a pulse crop with high nutritional quality (Lobo et al. 2010; Sperotto and Ricachenevsky 2017). For the low-income segment of the population, common bean plays a strategic role in alleviating malnutrition problems (Svetleva et al. 2006).

Diversity within a crop species is very crucial in future breeding, as well as for developing new products and consequently needs to be preserved for future generations (Negri and Tosti 2002; Stoilova et al. 2005). Genetic diversity is found between species, subspecies, varieties, population or individuals. It can be measured at the morphological and agronomic level (Singh 2001), the physiological level, diversity in a plant's resistance to pest and disease or in its degree of tolerance to abiotic stress and in terms of differences in biochemical, protein and molecular (DNA) properties within and between plant populations (Beebe et al. 2000; Ibushoska et al. 2016). Genetic diversity is the basis of several breeding programs to create varieties adapted to different biotic and abiotic factors (Kebebew et al. 2001; Ibushoska et al. 2016). This 
is used to estimate the existing diversity and suggest appropriate plans for the management and improvement of genetic resources in the future (Schut et al. 1997).

Common bean is a morphologically diverse crop having difference in their growth habit, pigmentation, pod, seed and phenology traits (Singh et al. 1991; Leakey 1988). This diversity reflects the wide range of ecological and human environments under which the crop has evolved over a long period of time (Singh et al. 1991; Francesc et al. 2017). Common bean is an important legume crop in Ethiopia, a country in which the legume family holds the highest number of species (about 10\% of the flora) containing many leguminous crop species known for rich inter and intraspecific diversity (Bareke et al. 2018). Among the grain legumes cultivated in Ethiopia, common beans are regarded as the most important crop for food security and wealth creation (Asfaw and Blair 2014). It contributes to the national economy as both a food and an export commodity, in both cases serving as a source of income and employment (Tumsa et al. 2014).

In Ethiopia, there is considerable potential of common bean genetic diversity which needs renewed conservation efforts for the region (Asfaw et al. 2009; Bareke et al. 2018). For conservation and breeding priorities landraces characterization is very important. Therefore, the main purpose of this study was to describe the morphological variation in common bean local populations from germplasm collection and to identify potentially useful landraces for future production and breeding.

\section{MATERIALS AND METHODS}

\section{Research site}

The study was conducted at Melkassa Agricultural Research Center in Adama District, and Rift Valley of Ethiopia (Figure 1).

\section{Plant materials}

The materials used in this study were 24 common beans (Phaseolus vulgaris L.) landraces (Table 1). The landraces were collected from different geographic locations of Oromia and Southern Nations, Nationalities and Peoples (SNNP) regions of Ethiopia (Bareke et al. 2018).

\section{Field experiment}

Sowing was done at the experimental field of the Melkassa Agricultural Research Center using irrigation fed. The experiment was arranged in a randomized complete block design, with three replications for one season, on an experimental plot of $1.2 \mathrm{~m}^{2}$ with 20 plants per plot. To keep proper spacing and avoid nutrient competition, space required is $10 \mathrm{~cm}$ among plants and $60 \mathrm{~cm}$ between rows (IBPGR, 1982) respectively. Space required for water movement was $1 \mathrm{~m}$ and space required between replication was $1.5 \mathrm{~m}$. Fertilizer rate used was the mix of $120 \mathrm{~kg}$ DAP and $60 \mathrm{~kg}$ urea per hectare.

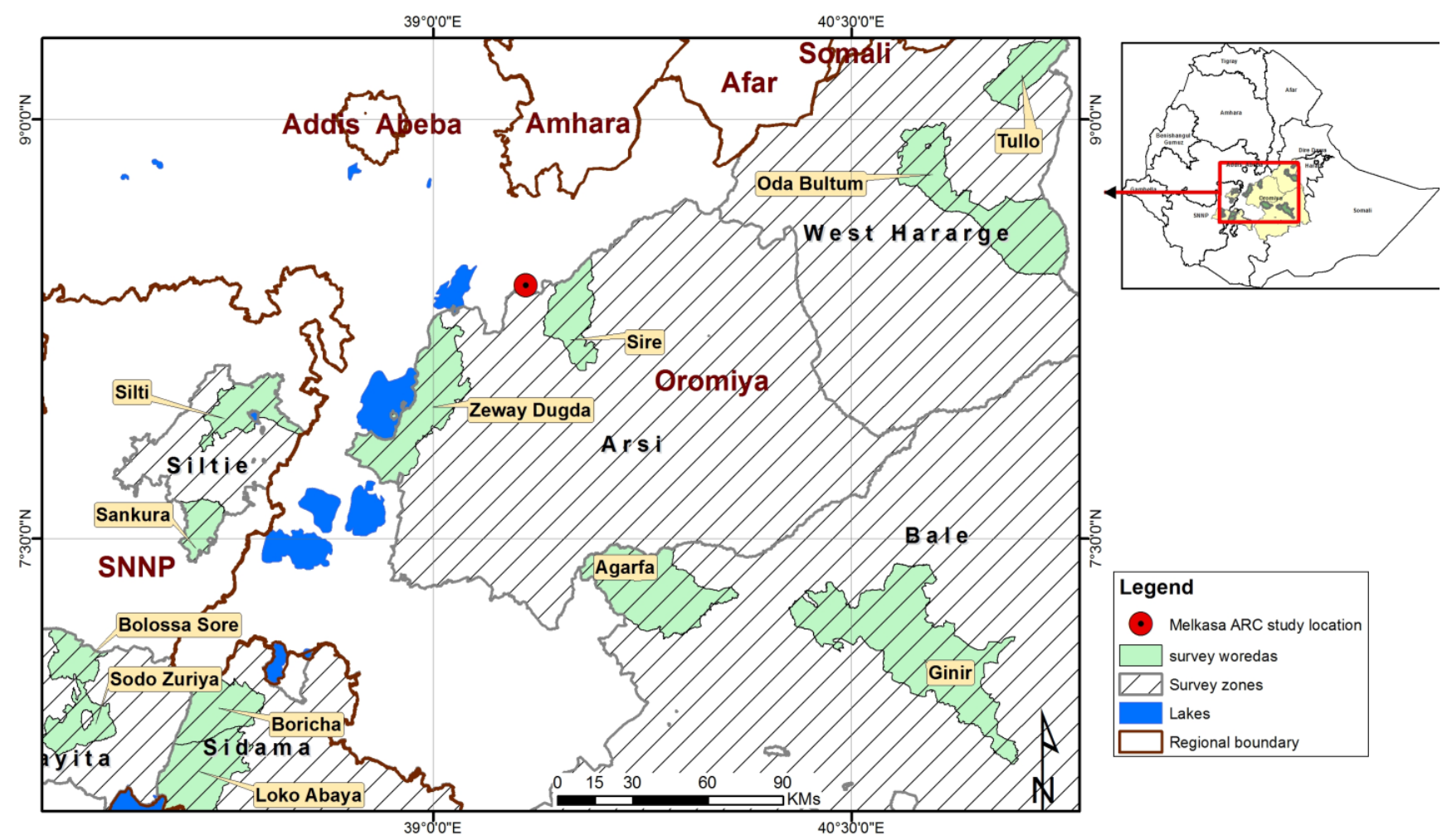

Figure 1. Map of Ethiopia showing the regions, zones and weredas (districts) of common bean seed collection and study site 
Table 1. List of common bean landraces included, along with collection and accession numbers, coordinates and region of collection sites

\begin{tabular}{|c|c|c|c|c|c|}
\hline $\begin{array}{l}\text { Accession } \\
\text { No. } \\
\end{array}$ & $\begin{array}{l}\text { Lat. (N) } \\
\text { (dd mm ss) }\end{array}$ & $\begin{array}{l}\begin{array}{l}\text { Lon. (E) } \\
\text { (dd mm ss) }\end{array} \\
\end{array}$ & $\begin{array}{l}\text { Alt. } \\
\text { m asl. }\end{array}$ & Region & Landrace name \\
\hline TBK109 & $08^{0} 19^{\prime} 02.4^{\prime \prime}$ & $039^{0} 28^{\prime} 48.3^{\prime \prime}$ & 1745 & Oromia & Dima Tikka \\
\hline TBK117 & $08^{0} 03^{\prime} 19.3^{\prime \prime}$ & $038^{0} 57^{\prime} 39.4^{\prime \prime}$ & 1660 & Oromia & Abbajolle \\
\hline TBK128 & $08^{0} 06^{\prime} 05.4^{\prime \prime}$ & $038^{0} 58^{\prime} 46.8^{\prime \prime}$ & 1673 & Oromia & Dalacha Dima \\
\hline TBK130 & $08^{0} 02^{\prime} 51.6^{\prime \prime}$ & $039^{\circ} 00 ' 35.9^{\prime \prime}$ & 1682 & Oromia & Bora \\
\hline TBK058 & $07^{0} 12^{\prime} 35.6^{\prime \prime}$ & $040^{0} 33^{\prime} 25.1^{\prime \prime}$ & 2143 & Oromia & Bar Bolokke \\
\hline TBK062 & $07^{0} 09^{\prime} 53.3^{\prime \prime}$ & $040^{0} 38^{\prime} 53.7^{\prime \prime}$ & 1995 & Oromia & Mishigani \\
\hline TBK138 & $07^{0} 19^{\prime} 43.1^{\prime \prime}$ & $039^{0} 51 ' 36.3^{\prime \prime}$ & 2401 & Oromia & Zale Wehy \\
\hline TBK141 & $07^{0} 19^{\prime} 43.1^{\prime \prime}$ & $039^{0} 51^{\prime} 36.3^{\prime \prime}$ & 2401 & Oromia & Dobole \\
\hline ТВK010 & o8 $8^{0} 52^{\prime 22} .6^{\prime \prime}$ & $040^{\circ} 41^{\prime} 02.0^{\prime \prime}$ & 1809 & Oromia & Bora Chulukkisa \\
\hline ТВK018 & o8 $8^{0} 53^{\prime} 35.3^{\prime \prime}$ & $040^{0} 43 ' 20.1^{\prime \prime}$ & 1760 & Oromia & Dima \\
\hline TBK038 & o9 $9^{0} 12^{\prime} 52.5^{\prime \prime}$ & $041^{0} 06^{\prime} 12.7^{\prime \prime}$ & 2180 & Oromia & Adi Battee \\
\hline ТВK040 & o9 $9^{0} 10^{\prime} 43.2^{\prime \prime}$ & $041^{0} 03 ' 22.2^{\prime \prime}$ & 2180 & Oromia & Kalibushay \\
\hline ТВК043 & $06^{0} 57^{\prime} 37.3^{\prime \prime}$ & $038^{0} 20^{\prime} 08.9^{\prime \prime}$ & 1856 & SNNP & Yumbube \\
\hline TBK152 & $06^{0} 41^{\prime} 54.4^{\prime \prime}$ & $038^{0} 15^{\prime} 56.1^{\prime \prime}$ & 1686 & SNNP & Logoma Wajjo \\
\hline TBK051 & $06^{0} 57^{\prime} 37.2^{\prime \prime}$ & $038^{0} 20^{\prime} 08.8^{\prime \prime}$ & 1860 & SNNP & Adi Tikko \\
\hline ТВК048 & $06^{0} 57^{\prime} 37.2^{\prime \prime}$ & $038^{0} 20^{\prime} 08.8^{\prime \prime}$ & 1860 & SNNP & Dume \\
\hline ТВK080 & 07059'59.7" & $038^{0} 18^{\prime} 42.4^{\prime \prime}$ & 2190 & SNNP & Zoolokoma \\
\hline ТВК090 & $08^{0} 03^{\prime} 56.1^{\prime \prime}$ & $038^{0} 21^{\prime} 47.5^{\prime \prime}$ & 2173 & SNNP & Arusicho \\
\hline ТВК091 & $08^{0} 03^{\prime} 56.1^{\prime \prime}$ & $038^{0} 21^{\prime} 47.5^{\prime \prime}$ & 2173 & SNNP & Logoma Dume \\
\hline ТВК093 & $08^{0} 03^{\prime} 56.1^{\prime \prime}$ & $038^{0} 21^{\prime} 47.5^{\prime \prime}$ & 2173 & SNNP & Zoolokoma Kareta \\
\hline TBK070 & $06^{0} 46^{\prime} 10.8^{\prime \prime}$ & $037^{0} 45^{\prime} 04.6^{\prime \prime}$ & 1872 & SNNP & Dima Burre \\
\hline TBK073 & $06^{0} 41^{\prime} 56.4^{\prime \prime}$ & $037^{0} 45^{\prime} 44.1^{\prime \prime}$ & 1995 & SNNP & Gardoy Bushay \\
\hline ТВK067 & $07^{0} 06^{\prime} 25.7^{\prime \prime}$ & $037^{0} 43^{\prime} 04.1^{\prime \prime}$ & 1719 & SNNP & Walensu \\
\hline TBK068 & $06^{0} 46^{\prime} 11.8^{\prime \prime}$ & $037^{0} 45^{\prime} 03.3^{\prime \prime}$ & 1859 & SNNP & Gumaray \\
\hline
\end{tabular}

Source: Bareke (2016)

\section{Traits observation}

Eight (8) descriptors of common bean were evaluated according to the IBPGR (1982) protocol for each landrace. Data were recorded on plant basis from plant height $(\mathrm{PH})$ $(\mathrm{cm})$, height to the first poding node (HFPN) $(\mathrm{cm})$, number of pods per plant (PPL), number of seeds per pod (SPO) and number of seeds per plant. Five plants were randomly selected from each plot and tagged with string and 10 seeds were received to determine the seed size (seed length, width, and thickness).

\section{Data analysis}

One-way ANOVA was used to analyze the significant difference among landraces on the basis of their morphological traits.

The classification of landraces based on morphological traits was made using dendrogram which was generated using R software (R Core Development Team 2011).

The estimate of genetic components and heritability for each trait was calculated using the following formula according to Feher (1987).

Heritability $(\mathrm{bs})=\delta 2 \mathrm{~g} / \delta^{2} \mathrm{p}$

Where,

Genetic variance $(\delta 2 \mathrm{~g})=$ MSG-MSE$/ \mathrm{r}$

Phenotypic variance $(\delta 2 p)=\mathrm{MSG} / \mathrm{r}$

MSG = Genetic mean squares from the analysis of variance (ANOVA)

MSE $=$ Error mean square of ANOVA

$\mathrm{R}=$ number of replications

\section{RESULTS AND DISCUSSION}

\section{Results}

The mean height of Zoolokoma Kareta was significantly different $(p<0.05)$ from all landraces with the highest values whereas, Abbajolle was the shortest. The mean heights of common bean landraces were found between 37 to167 centimeters (Table 2). Dima burre has the longest height to first pod node than other landraces followed by Gardoy bushay and Zoolokoma Kareta while the Adi tikko was the shortest. Statistically, Zale wehy was significantly different $(p<0.05)$ from all landraces with the highest mean number of pods per plant. This was followed by Gumaray while Abbajolle has the lowest pods per plant. Mean number of seeds per pod was significantly $(\mathrm{p}<0.05)$ higher for Dobole followed by Dima, Kalibushay and Adi Tikko while Logoma Dume has the lowest number of seeds per pod. The mean number of seeds per pod of common bean landraces was found between 3.5 and 7.3. On the other hand, the mean number of seed per plant was significantly $(\mathrm{p}<0.05)$ higher for Zale wehy while the lowest for Logoma Dume (Table 2).

The average number of seeds per pod had inverse relationship with seed size. As seed size increases the number of seeds per pod decreased (Figure 2). 
Table 2. Mean height of plant (HP) (cm), height to first pod node (HFPN) (cm), number of pods per plant (PPL), number of seeds per pod (SPO) and number of seed per plant (SPL) \pm standard deviation (SD) of common bean landraces

\begin{tabular}{|c|c|c|c|c|c|}
\hline Landraces & $H P \pm S D$ & HFPN + SD & PPL + SD & $\mathrm{SPO} \pm \mathrm{SD}$ & SPL \pm SD \\
\hline Abbajolle & $36.5 \pm 6.0 n$ & $12.1 \pm 1.6 \mathrm{de}$ & $25.4+11.9 n$ & $4.5 \pm 1.0 \mathrm{fg}$ & $114 \pm 25 n$ \\
\hline Adi Batte & $103.1 \pm 18.3 \mathrm{bcd}$ & $11.2 \pm 1.8 \mathrm{def}$ & $67.4 \pm 21.6 \mathrm{efgh}$ & $6.7 \pm 1.1 \mathrm{~b}$ & $454 \pm 77 f$ \\
\hline Adi Tikko & $61+6 \overline{l m}$ & $4.5+0.8 \mathrm{~m}$ & $88+\overline{9} .3 \mathrm{bcd}$ & $6.9+1.1 \mathrm{ab}$ & $604+97 c$ \\
\hline Arusicho & $97 . \overline{1} \pm 11.9 \mathrm{cde}$ & $7.6 \pm 1.6 \mathrm{ij}$ & $51 . \overline{4} \pm 16.1 \mathrm{hijk}$ & $4.3 \pm 1.3 \mathrm{~g}$ & $223 \pm 651 \mathrm{~m}$ \\
\hline Bar Bolokke & $104.7 \pm 14.5 b c$ & $12.9 \pm 2.9 \mathrm{~cd}$ & $50.2+7 \mathrm{ijk}$ & $5.1 \pm 1.2 \mathrm{e}$ & $254 \pm 6 \mathrm{kl}$ \\
\hline Bora & $112 \pm 12.5 b$ & $12.3 \pm 2.8 \mathrm{de}$ & $26 \pm 13.6 \mathrm{mn}$ & $4.9 \pm 1.4 \mathrm{efg}$ & $127 \pm 37 n$ \\
\hline Bora Chulukkisa & $79.8 \pm 8.8 \mathrm{hij}$ & $8.5 \pm 4.4 \mathrm{hi}$ & $78 . \overline{4} \pm 15.8 \mathrm{cdef}$ & $6.4 \pm 1.1 \mathrm{bcd}$ & $444 \pm 135 \mathrm{fg}$ \\
\hline Dalacha Dima & $90.3+21.5 \mathrm{efg}$ & $14 . \overline{7}+3.8 \mathrm{c}$ & $41.8+13.7 \mathrm{jklm}$ & $5.3 \pm 1.2 \mathrm{e}$ & $220+5 \operatorname{lm}$ \\
\hline Dima & $70.4 \pm 3.7 \mathrm{jkl}$ & $8.8 \pm 1.3 \mathrm{hi}$ & $60.4 \pm 27.3 \mathrm{ghi}$ & $6.9 \pm 1.1 \mathrm{ab}$ & $415+66 \mathrm{gh}$ \\
\hline Dima Burre & $81.6 \pm 9.3 \mathrm{ghi}$ & $26 \pm 3.3 \mathrm{a}$ & $41.2 \pm 13.5 \mathrm{jklmn}$ & $5.1 \pm 1.1 \mathrm{e}$ & $209 \pm 44 m$ \\
\hline Dima Tikka & $81.6 \pm 21.3 \mathrm{ghi}$ & $9.8 \pm 2.5 \mathrm{gh}$ & $52.4+11.5 \mathrm{hijk}$ & $5.2 \pm 1.2 \mathrm{e}$ & $260 \pm 71 \mathrm{jk}$ \\
\hline Dobole & $58.3 \pm 7.5 \mathrm{~m}$ & $9.5 \pm 5.5 \mathrm{gh}$ & $58.1 \pm 16.17 \mathrm{hij}$ & $7.3 \pm 1.4 a$ & $398 \pm 92 \mathrm{~h}$ \\
\hline Dume & $62.7 \pm 61 \mathrm{~m}$ & $5.4 \pm 1.2 \mathrm{~lm}$ & $81.6 \pm 26 \mathrm{bcde}$ & $4.8 \pm 1.1 \mathrm{efg}$ & $392 \pm 86 h$ \\
\hline Gardoy Bushay & $62.3+5.91 \mathrm{~m}$ & $21.3+2.3 b$ & $31 \pm \overline{7} .91 \mathrm{mn}$ & $4.4+1.0 \mathrm{fg}$ & $136 \pm 3 n$ \\
\hline Gumaray & $73.9+6.3 \mathrm{ijk}$ & $6.7+1.8 \mathrm{ijkl}$ & $96.8+11.9 b$ & $6.6+1.2 \mathrm{bc}$ & $639+112 b$ \\
\hline Kalibushay & $77.1+11.8 \mathrm{hij}$ & $12.7+3.2 \mathrm{~d}$ & $65+8.5$ fghi & $6.8+1.1 \mathrm{ab}$ & $442+73 f g$ \\
\hline Logoma Dume & $83.9+25.5 \mathrm{ghi}$ & $7.3+1.2 \mathrm{ijk}$ & $36+10.3 \mathrm{klmn}$ & $3.5+1.0 \mathrm{~h}$ & $124.8+35 n$ \\
\hline Logoma Wajjo & $70.2+8.8 \mathrm{jkl}$ & $11.6+2.5 \mathrm{def}$ & $55.6+13.1 \mathrm{hij}$ & $6.4+1.2 \mathrm{bcd}$ & $291+14 j k$ \\
\hline Mishigani & $106 \pm 9.3 \mathrm{bc}$ & $11.4 \pm 2 \mathrm{def}$ & $50.4 \pm 7.9 \mathrm{ijk}$ & $6.6 \pm 1.0 \mathrm{bc}$ & $333 \pm 48 i$ \\
\hline Walensu & $93.3 \pm 5.8 \mathrm{def}$ & $10.4 \pm 2.1 \mathrm{efgh}$ & $74.4 \pm 43 \mathrm{defg}$ & $6.6 \pm 1.5 \mathrm{bc}$ & $491 \pm 112 \mathrm{e}$ \\
\hline Yumbube & $97.3+8.1 \mathrm{cde}$ & $5.7 \pm 1.8 \mathrm{klm}$ & $60.2+14.6 \mathrm{ghi}$ & $4.9+1.2 \mathrm{ef}$ & $297 \pm 72 \mathrm{ij}$ \\
\hline Zalewehy & $82+4.5 \mathrm{ghi}$ & $8.7+1.3 \mathrm{hi}$ & $122.7+40.5 a$ & $6.1+1.1 \mathrm{~cd}$ & $752+135 a$ \\
\hline Zoolokoma & $85.6+17.7 \mathrm{fgh}$ & $9.9+1.7 \mathrm{fgh}$ & $55.8+10.7 \mathrm{hij}$ & $5.9+1.5 d$ & $331+81 i$ \\
\hline Zoolokoma Kareta & $166 . \overline{8}+13.2 \mathrm{a}$ & $21 . \overline{4}+2 b$ & $91+\overline{1} 1.3 b c$ & $6.1+1.2 \mathrm{~cd}$ & $558+105 d$ \\
\hline
\end{tabular}

Note: different letters show significant differences

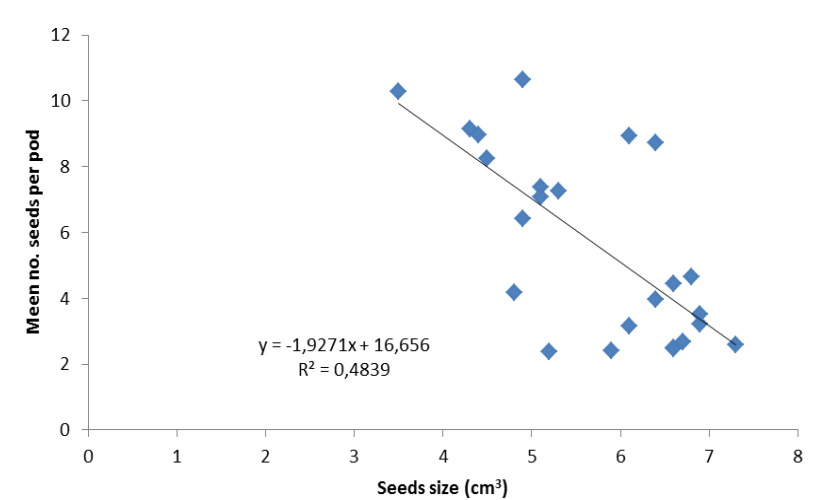

Figure 2: Relationships between seed size and number of seeds per pod

Mean seed length of Logoma dume and Gardoy bushay were the highest and significantly different $(p<0.05)$ from other landraces whereas the mean seed length of Mishigani was significantly different from other landraces with the lowest seed length. In terms of mean seed width Arusicho was significantly different $(\mathrm{p}<0.05)$ from the rest with the highest mean, whereas Dima tikka was significantly different $(p<0.05)$ from other landraces with the lowest mean seed width. Mean seed thickness of Yumbube was significantly different $(\mathrm{p}<0.05)$ from other landraces with the biggest mean, while Zoolokoma was significantly different $(\mathrm{p}<0.05)$ with smallest mean. Yumbube has the highest mean seed size and significantly different from the rest, whereas, Dima tikka has the smallest seed size when compared to other landraces. As the name implies Dima tikka was the smallest in seed size among all landraces under study. Seed length of common bean landraces has a range of $8.62-16.69 \mathrm{~mm}$, width $5.81-10.21 \mathrm{~mm}$, and thickness 4.18-8.46 mm (Table 3).

The highest diversity (5.2) was found in number of seed per plant among landraces while the lowest diversity was found in number of seed per pod (Table 4). This indicates that there is a huge variation among landraces in terms of number of seed per plants and on the other hand, number of seed per pod is almost similar.

Table 4. Shannon diversity index (H'), maximum diversity (Hmax) and Evenness (E) for traits in 24 common bean landraces evaluated during 2016 at the Adama, Ethiopia

\begin{tabular}{lllc}
\hline \multicolumn{1}{c}{ Traits } & $\begin{array}{c}\text { Shannon } \\
\text { diversity } \\
\text { index } \\
\left(\mathbf{H}^{\prime}\right)\end{array}$ & Hmax & $\begin{array}{c}\text { Even- } \\
\text { ness } \\
(\mathbf{E})\end{array}$ \\
\hline Height of landraces (cm) & 3.1 & 5.12 & 0.61 \\
Height to the first poding node (cm) & 3 & 3.06 & 0.98 \\
Number of pods per plant & 3.1 & 4.81 & 0.64 \\
Number of seed per pod & 0.24 & 1.95 & 0.12 \\
Number of seed/plant & 5.2 & 6.62 & 0.79 \\
Seed length (mm) & 2.2 & 2.82 & 0.78 \\
Seed width (mm) & 1.8 & 2.32 & 0.77 \\
Seed thickness (mm) & 1.3 & 2.14 & 0.61 \\
\hline
\end{tabular}


Table 3. Seed length, width and thickness (mm; mean \pm standard deviation (s.d.)) of landraces

\begin{tabular}{|c|c|c|c|}
\hline Landrace & Seed length (mm) & Seed width $(\mathrm{mm})$ & Seed thickness $(\mathrm{mm})$ \\
\hline Abbajolle & $15.15 \pm 0.73^{b}$ & $7.91 \pm 0.48^{\text {gh }}$ & $6.88 \pm 0.48^{c}$ \\
\hline Adi battee & $9.04+0.6 \mathrm{hi}$ & $6.32+0.43 \mathrm{klmn}$ & $4.7+0.3 \mathrm{klmn}$ \\
\hline Adi tikko & $9.61+0.51^{\mathrm{gh}}$ & $6.52+0.44 \mathrm{kl}$ & $5.12+0.41$ hij \\
\hline Arusicho & $13.6 \pm 0.6^{\mathrm{cd}}$ & $10.21 \pm 0.42^{a}$ & $6.58 \pm 0.27^{\mathrm{cd}}$ \\
\hline Bar bolokke & $12.67 \pm 0.6^{\mathrm{e}}$ & $9.6 \pm 0.48^{b c}$ & $6.06 \pm 0.34$ ef \\
\hline Bora & $12.84 \pm 0.38 \mathrm{de}$ & $8.92 \pm 0.32^{\mathrm{de}}$ & $5.6 \pm 0.21^{\mathrm{g}}$ \\
\hline Bora Chulukkisa & $10.85 \pm 0.82^{f}$ & $7.46 \pm 0.39 \mathrm{hi}$ & $4.89 \pm 0.41^{\mathrm{jkl}}$ \\
\hline Dalacha dima & $13.92 \pm 0.47^{\mathrm{c}}$ & $8.49 \pm 0.43^{\text {ef }}$ & $6.13 \pm 0.3$ ef \\
\hline Dima & $10.87 \pm 0.7^{\mathrm{f}}$ & $6.69 \pm 0.44^{\mathrm{jk}}$ & $4.83 \pm 0.3^{\mathrm{jklm}}$ \\
\hline Dima burre & $15.04+0.55^{b}$ & $8.04+0.44^{\mathrm{fg}}$ & $5.85+0.5 \mathrm{fg}$ \\
\hline Dima tikka & $9.37+0.64$ ghi & $5.81+0.44^{n}$ & $4.36+0.19$ no \\
\hline Dobole & $9.73 \pm 0.8^{\text {gh }}$ & $6.1+0.281 \mathrm{mn}$ & $4.34+0.17$ no \\
\hline Dume & $11.21 \pm 0.6^{\mathrm{f}}$ & $7.33+0.66^{i}$ & $5.08+0.4 \mathrm{ijk}$ \\
\hline Gardoy bushay & $15.97 \pm 0.86^{\mathrm{a}}$ & $8.92 \pm 0.49 \mathrm{de}$ & $6.3+0.54$ de \\
\hline Gumaray & $9.47 \pm 0.5^{\text {gh }}$ & $5.92+0.32^{\mathrm{mn}}$ & $4.45+0.2^{\mathrm{mno}}$ \\
\hline Kalibushay & $11.51 \pm 0.6^{\mathrm{f}}$ & $7.38+0.37 \mathrm{hi}$ & $5.47 \pm 0.2 \mathrm{ghi}$ \\
\hline Logoma dume & $16.69+0.82^{a}$ & $8.86+0.48$ de & $6.96+0.46^{c}$ \\
\hline Logoma wajjo & $14.86 \pm 0.76^{b}$ & $9.25 \pm 0.52^{\mathrm{cd}}$ & $6.34+0.6^{\mathrm{de}}$ \\
\hline Mishigani & $8.62+0.6^{i}$ & $6.18+0.31 \mathrm{klmn}$ & $4.64+0.32^{l m n}$ \\
\hline Walensu & $11.4 \pm 0.7^{\mathrm{f}}$ & $7.08 \pm 0.388^{\mathrm{ij}}$ & $5.5 \pm 0.35^{\mathrm{gh}}$ \\
\hline Yumbube & $12.45 \pm 0.45^{\mathrm{e}}$ & $10.11 \pm 0.6^{\mathrm{ab}}$ & $8.46 \pm 0.39^{a}$ \\
\hline zalewehy & $12.38 \pm 0.72^{\mathrm{e}}$ & $9.10 \pm 0.37^{d}$ & $7.93 \pm 0.32^{b}$ \\
\hline Zoolokoma & $9.77 \pm 0.48^{g h}$ & $5.92 \pm 0.3 \mathrm{mn}$ & $4.18 \pm 0.33^{\circ}$ \\
\hline Zoolokoma kareta & $10.02+1.18^{\mathrm{g}}$ & $6.39 \pm 0.99 \mathrm{klm}$ & $4.94 \pm 0.6^{\mathrm{jkl}}$ \\
\hline
\end{tabular}

Note: different letters show significance difference. Data are presented as mean \pm s.d.

Based on morphological traits similarities those 24 landraces were classified into 4 major categories (Figure 3). Accordingly, Group I: 1. Abbajolle 6. Bora .17 Logoma Wajjo 14. Gardoy Bushay; GrouP II: 4. Arusicho 8. Dalacha Dima 9. Dima Burre 5. Bar Boloke 10. Dima Tikka 18. Logoma Dume 19. Mishigani 21. Yumbube 24. Zoolokoma; Group III: 7. Bora Chulukkisa 11. Dima 12. Dobole 13. Dume 16. Kalibushay 2. Adi Battee 20. Walensu; Group IV: 3. Adi TIKKO 15. Gumaray 22. Zale Wehy 23. Zoolokoma Kareta.

As shown in Table 5, number of seed per pod was positively correlated $(\mathrm{P} \leq 0.001)$ with number of seed per plant $(r=0.734)$. These implied that when number of seeds in pods increased, the number of seeds per plant also increased. On the other hand, it was negatively correlated with seed length $(\mathrm{p}<0.001)$, seed width and thickness $(p<0.01)$. Number of seed per plant was negatively correlated with seed length and width. Seed length has strong and direct relationship with seed width and thickness (Table 5).

Seed width of common bean landraces was highly correlated $(\mathrm{p}<0.001)$ with seed length and thickness. In addition to this, seed width was negatively correlated with number of seed per pod $(\mathrm{p}<0.01)$ and number of seed per plant $(\mathrm{p}<0.05)$.

Genetic differences among the populations for all traits were highly significant $(\mathrm{P}<0.001)$. The coefficient of variation was the highest for number of seed per pod while the lowest for number of seed per plant among the landraces (Table 6).

Heritability was the highest for seed length (0.97) and the lowest $(0.1)$ for height of plant and the rest found between these values (Table 7).

\section{Discussion}

The characterization and evaluation of the available common bean landraces germplasm are very important to facilitate breeding efforts. Variation in the genetic constitution of breeding populations may result in the observed variability, which may be manipulated for further breeding. Air temperature and rainfall patterns greatly affect the growth and development of common bean plants as well as morphological traits and productivity (Mouhouche et al. 1998).

The height of common bean plant has variation ranging from 37 to $167 \mathrm{~cm}$ based on their growth habits. Climber landraces has the longest height than erected landraces. For example, Zoolokoma Kareta is a climber landrace that has the longest height while Abbajolle is erect with the shortest height. Similarly in Brazilian, the plant height of common bean landraces have a lot of variation ranging from 33.8 to $98.8 \mathrm{~cm}$ (Bertoldo et al. 2014). On the other hand, the plant height of common bean landraces in Portugal and Bulgaria ranges from 19.5 to $123.4 \mathrm{~cm}$ (Stoilova et al. 2013). In addition to this in Turkey, the plant height of common bean landraces were ranged from 20 and $310 \mathrm{~cm}$ (Sozen et al. 2014). 


\section{Agglomerative Hierarchical Classification}

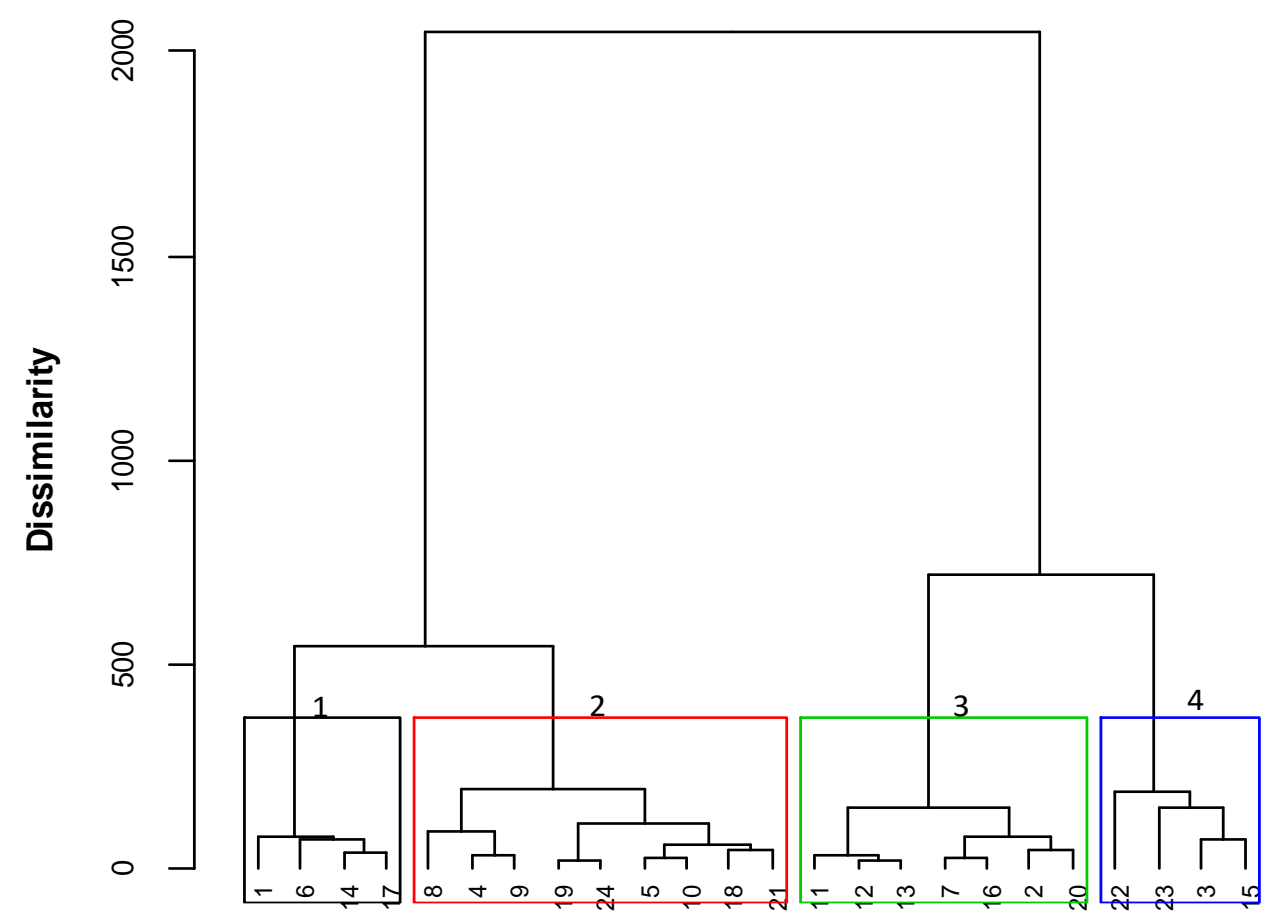

Landraces

Figure 3. Agglomerative hierarchical classification of landraces based on phenological traits based on morphological traits. Note: 1 . Abbajolle 2. Adi Battee 3. Adi Tikko 4. Arusicho 5. Bar Boloke 6. Bora 7. Bora Chulukkisa 8. Dalacha Dima 9. Dima Burre 10. Dima Tikka 11. Dima 12. Dobole 13. Dume 14. Gardoy Bushay 15. Gumaray 16. Kalibushay 17. Logoma Wajjo 18. Logoma Dume 19. Mishigani 20. Walensu 21. Yumbube 22. Zale Wehy 23. Zoolokoma Kareta 24. Zoolokoma

Table 5. Correlations among all examined variables in common bean landraces at Adama, Ethiopia

\begin{tabular}{|c|c|c|c|c|c|c|c|c|}
\hline \multicolumn{8}{|c|}{$\begin{array}{c}\text { Pearson Correlation Coefficients, } N=24 \\
\text { Prob }>|\mathbf{r}| \text { under H0: } \text { Rho }=0\end{array}$} & \\
\hline & & HFPN & NPP & NSPO & NSPL & SL & SW & ST \\
\hline$\overline{\mathrm{HL}}$ & 1 & 0.329 & 0.183 & -0.026 & 0.089 & -0.177 & 0.063 & -0.007 \\
\hline HFPN & 0.329 & 1 & 0.109 & -0.156 & -0.302 & 0.352 & 0.072 & 0.005 \\
\hline NPP & 0.183 & 0.109 & 1 & 0.131 & 0.192 & -0.055 & -0.001 & 0.050 \\
\hline NSPO & -0.02631 & -0.156 & 0.131 & 1 & $0.734 * * *$ & $-0.721 * * *$ & $-0.615^{* *}$ & $-0.532 * *$ \\
\hline NSPL & 0.089 & -0.302 & 0.192 & $0.734 * * *$ & 1 & $-0.633 * *$ & $-0.4317^{*}$ & -0.231 \\
\hline SL & -0.177 & 0.352 & -0.055 & $-0.721^{* * *}$ & $-0.633^{* *}$ & 1 & $0.766 * * *$ & $0.706 * * *$ \\
\hline SW & 0.063 & 0.072 & -0.001 & $-0.615^{* *}$ & $-0.431 *$ & $0.766^{* * *}$ & 1 & $0.860 * * *$ \\
\hline ST & -0.007 & 0.005 & 0.050 & $-0.532^{* *}$ & -0.231 & $0.706^{* * *}$ & $0.860 * * *$ & 1 \\
\hline
\end{tabular}

Note: $*=$ Significant at $\mathrm{p}<0.05, * *=$ Significant at $\mathrm{p}<0.01, * * *=$ Significant at $<0.001$

Table 6. ANOVA and coefficient of variation for traits in 24 common bean landraces evaluated during 2016 at the Adama, Ethiopia

\begin{tabular}{|c|c|c|c|c|c|}
\hline \multirow{2}{*}{ Traits } & \multicolumn{5}{|c|}{ Mean squares } \\
\hline & Landraces & Error & Reps & F-ration & CV\% \\
\hline Height of plant $(\mathrm{cm})$ & $1.3^{* * *}$ & 0.02 & 0.1 & 41.8 & 3.2 \\
\hline Height to the first poding node $(\mathrm{cm})$ & $2.8^{* * *}$ & 0.05 & 0.2 & 35.3 & 9.7 \\
\hline Number of pods per plant & $2.6 * * *$ & 0.11 & 0.5 & 15 & 8.3 \\
\hline Number of seed per pod & $11.24 * * *$ & 0.7 & 1 & 12.07 & 14 \\
\hline Number of seed/plant & $4.5^{* * *}$ & 0.03 & 0.7 & 1.3 & 3 \\
\hline Seed length $(\mathrm{mm})$ & $105.6 * * *$ & 0.42 & 0.97 & 137.7 & 5.5 \\
\hline Seed width (mm) & $40.4 * * *$ & 0.22 & 0.3 & 101.96 & 6.15 \\
\hline Seed thickness $(\mathrm{mm})$ & $24.5^{* * *}$ & 0.13 & 0.14 & 100 & 6.59 \\
\hline *** Highly significant at $0.1 \%$ probability level & & & & & \\
\hline
\end{tabular}


Table 7. Genetic variance $(\delta 2 \mathrm{~g})$, phenotypic variance $(\delta 2 \mathrm{p})$ and heritability h2 (bs) for various traits in common bean landraces

\begin{tabular}{llll}
\hline Traits & $\boldsymbol{\delta}^{\mathbf{2}} \mathbf{g}$ & $\boldsymbol{\delta}^{\mathbf{2}} \mathbf{p}$ & $\mathbf{h}^{\mathbf{2}}(\mathbf{b s})$ \\
\hline Height of plant (cm) & 1.1 & 13 & 0.09 \\
Height to the first poding node $(\mathrm{cm})$ & 2.55 & 14 & 0.18 \\
Number of pods per plant & 2.38 & 5.2 & 0.46 \\
Number of seeds per pod & 10.54 & 11.24 & 0.94 \\
Number of seeds per plant & 4.46 & 6.43 & 0.69 \\
Seed length (mm) & 105.17 & 108.87 & 0.97 \\
Seed width (mm) & 39.67 & 134.67 & 0.3 \\
Seed thickness (mm) & 23.57 & 175 & 0.14 \\
\hline
\end{tabular}

Averages and ranges for the common bean genotypes indicate considerable genotypic variation including number of seed per pod, number of seeds per plant, number of pods per plant, seed, length, width, and thickness. This diversity is also due to rising of the traditional farming in which these are landrace accessions characterized by low selective pressure. High genotype variation for yield components was also observed by Boros et al. (2014) and Stoilova et al. (2013) in the studies of common bean.

There was variation among common bean landraces in terms of number of seeds per pod ranging from 3.5 to 7.3. Similarly in Zimbabwe, the number of seeds per pod among the common bean landraces has comparable ranges from 3.60 to 5.53 (Musango et al. 2016). Wide variation was also recorded in an average number of pods per plant among common bean landraces which were found between 25.4 to 122.7 . Zale wehy landraces produced the highest pod yield per plant and the lowest yield was obtained from ABBAJOLLE. This is due to their growth habit and crown size. Many authors including John et al. (1987) and Bareke et al. (2014) also revealed that the more vegetative growth of plant species develops to more flowers, pods, and seeds, and also plants that grow longer vegetative before flowering are typically bigger and able to support more reproductive growth. Zale wehy, Gumaray, Adi tikko, Zoolokoma kareta, Walensu, Bora Chulukkisa, Adi batte, Kalibushay, Dima, Dobole, Dume, Logoma wajjo, Zoolokoma and Mishigani have the potential to produce more both seeds and pods yield per plants. Because, all of them are climber inhabit and have many branches which can hold a lot of pods.

Number of seed per pod was positively correlated with number of seed per plant. Similarly, Motlatsi et al. (2016) reported strong correlation between number of seed per pod and the number of seed per plant is very important to breeder because this character is relatively easy to determine the yield. The phenotypic correlations among traits reflect observed relationships between traits arising from the combined effects of genotype and environment, whereas genetic correlations estimate the association between traits, resulting in either from linkage or pleiotropic effects between the traits (Mudasir et al. 2012).

The result of this study revealed that the seed size of common bean landraces has big variation which is found between $237.4 \mathrm{~mm}^{3}$ and $1064.9 \mathrm{~mm}^{3}$. In addition to this, seed length of common bean landraces has a variation in a range of $8.62-16.69 \mathrm{~mm}$, width $5.81-10.21 \mathrm{~mm}$, and thickness $4.18-8.46 \mathrm{~mm}$. Similarly, study conducted by Fetahu et al. (2012) in Kosovo indicated that seed length of common bean landraces has a range of 12.8-18.3 mm, width 7.4-10.1 mm, and thickness 4.6-6.9 mm. Seed length also ranges from 10.0-16.7 mm, width $6.1-9.8 \mathrm{~mm}$, and thickness from 4.2-8.2 $\mathrm{mm}$ in Iran (Marzooghian et al., 2013).

A local variety which was big in seed size has few seeds number per pod; whereas, a variety which small in size has a higher number of seeds per pod. For example, Yumbube and Logoma dume varieties are big in seed size; though, the numbers of seeds per pod are the smallest for these varieties. On the other hand, Dima tikka was the smallest in seeds size; but the higher in numbers of seeds per pod. Hence, this study revealed that for big seed size variety numbers of seeds per pod are small in number while for small seed variety the number of seeds per pod is higher. Similar finding was reported by Boros et al. (2014) that landraces with small seeds had higher number of pods and seeds per plant, whereas large-seed types have fewer pods and seeds per plant. On the other hand, Elvis et al. (2005) were reported that large seed does not affect grain yield but reduced the number of seeds per pod. Larger seeds produce larger pods to compensate for the fewer pods per plant produced (Acquah et al. 1991). Sowing larger seeds of common bean can improve early-season plant growth, which might be advantageous for crop establishment in the stress environment (White et al. 1992). The differences in grain yield between large and smallseeded common bean varieties are likely to be a result of genetic adaptation to the region of domestication of the distinct gene pool (Sexton et al. 1994). Bigger seed size indicated better quality and germination on seeds and genetic potential (Davidson et al. 1996), but quality of the seeds may be related to some other factors such as variations in seed nutrient content, time of seed collection, genetic factor due to provenances or agroecology (Jayasankar et al. 1999).

Genetic variability, which is a heritable difference among landraces, is required at an appreciable level within a population to facilitate and sustain an effective long term plant breeding program. Progress from selection has been reported to be directly related to the magnitude of genetic variance in the population. The magnitude of genetic variability provides useful information with regard to the possibility and extent of improvement that may be expected in the characters through breeding and selection. The highest heritability estimates were observed for seed length (0.97) followed by number of seeds per pod (0.94) and seeds per plant (0.69). This indicates that a large portion of the variation is due to genetic factors. High Heritability of this trait indicates a wide range of variation and genetic differences among the populations. According to Idahosa (2010), if the heritability character is $70 \%$ or more, the selection for the trait could be fairly easy because the relationship between phenotypes and genotypes was relatively small contribution of environment to phenotype. 
In conclusion, morphological variation observed among landraces showed that there is enough scope for selection of suitable landraces for various production systems. The variability observed in height to the first poding node, number of pods per plant, number of seeds per pod, number of seeds per plant, seed length, seed width, and seed thickness could be utilized in variety improvement programs. Zale wehy, Gumaray, Adi tikko, Zoolokoma kareta, Walensu, Bora chulukkisa, Adi batte, Kalibushay, Dima, Dobole, Dume, Logoma Wajjo, Zoolokoma, and Mishigani produce more seeds per pod, pod per plant and seeds per plants. Therefore, crop breeders could give emphasis to these landraces to monitor and use for the breeding program, future production and for other domestic purposes.

\section{ACKNOWLEDGEMENTS}

I would like to thank the Holeta Bee Research Center and Oromia Agricultural Research Institute for providing required facilities and logistics. My sincere thanks are also to the Melkassa Agricultural Research Center for allocating land for the study. My sincere thanks also extended to Belete Dagne and Sirak Teshome, for their inspiration and support in the implementation and follow-up of the research from land preparation up to the end of the study.

\section{REFERENCES}

Acquaah G, Adams MW, Kelly JD. 1991. Identification of effective indicators of erect plant architecture in dry bean. Crop Sci 31: 261264.

Asfaw A, Blair MW, Almekinders C. 2009. Genetic diversity and population structure of common bean (Phaseolus vulgaris L.) landraces from the East Africa highlands. Theor Appl Genet 120: 112.

Asfaw A, Blair MW. 2014. Quantification of drought tolerance in Ethiopian common bean varieties. Agric Sci 5: 124-139.

Bareke T, Asfaw Z, Woldu Z, Beth M, Amssalu B. 2018. Diversity of common bean (Phaseolus vulgaris L., Fabaceae) landraces in parts of southern and eastern Ethiopia. Adv Plants Agric Res 8 (6): 449-457.

Bareke T. 2016. Landrace Diversity of Common Bean (Phaseolus vulgaris L., Fabaceae) in Parts of Oromia and SNNP Regions, Ethiopia. [Thesis]. Department of Plant Biology and Biodiversity Management, Addis Ababa University, Ethiopia.

Bareke TK, Wakjira KH, Addi AM. 2014. Screening of potential herbaceous honey plants for beekeeping development. Agric For Fish 3 (5) 386-391.

Beebe SE, Skroch PW, Tohme J, Duque MC, Pedraza F, Nienhuis J. 2000. Structure of genetic diversity among common bean landraces of Middle American origin based on correspondence analysis of RAPD. Crop Sci 40: 264-273.

Benz B, Perales H, Brush S. 2007. Tzeltal and Tzotzil farmer knowledge and maize diversity in Chiapas, Mexico. Curr Anthropol 48 (2): 289300.

Bertoldo JG, Coimbra JLM, Guidolin AF, de Andrade LRB, Nodari RO. 2014. Agronomic potential of gene bank landrace elite accessions for common bean genetic breeding. Sci Agric 71: 120-125.

Boros L, Wawer A, Borucka K. 2014. Morphological, phenological and agronomical characterization of variability among common bean (Phaseolus vulgaris) local populations from the national centre for plant genetic resources: Polish Genebank. J Hortic Res 22 (2): 123130.

Carovic-Stanko K, Liber Z, Vidak M, et al. 2017. Genetic diversity of Croatian common bean landraces. Front Plant Sci 8: 604.
Davidson RH, Edwards DW, Sziklai O, El-Kassaby YA. 1996. Variation in germination parameters among Pacific Silver fir populations. Silvae Genet 45: 165-171.

Elvis RL, Aline SS, Adelson PA, Marcelo G.T. 2005. Effects of the size of sown seed on growth and yield of common bean cultivars of different seed sizes. Braz. J Plant Physiol 17 (3): 273-281.

Fehr WR. 1987. Principles of cultivar development. Theor Technique 1: 351-353.

Fetahu S, Aliu S, Rusinovci I, Kelmendi B, Caka H, Maliqi N. 2012. Diversity of seeds size and weight of common beans landraces (Phaseolus vulgaris L.) in Kosovo. International Symposium on Agriculture, Opatija, Croatia.

Francesco C, Joan S, Joan C, Jaime P. 2017. Toward an evolved concept of landrace. J Front Plant Sci 8 (145): 1-7.

IBPGR [International Board for Plant Genetic Resources]. 1982. Phaseolus vulgaris descriptors. International Board for Plant Genetic Resources, Rome. Italy.

Ibushoska A, Ivanovska S, Agic R, Drvoshanova B. 2016. Investigation on Morphological Traits on Leaf, Pod and Seed of Local Bean (Phaseolus vulgaris L.) Populations in Macedonia. Journal of Agricultural, Food and Environmental Sciences 68: 56-62.

Idahosa DO., Alika JE, Omoregie AU. 2010. Genetic variability, Heritability and Expected genetic advance as Indices for yield components selection in cowpea. (Vigna unguiculata (L.) Walp). Academia Arena 2 (5): 22-26.

Ivanovska S, Jankulovska M, Ajruli G, Popsimonova G, Kratovalieva S, Agic R. 2012. Genetic variability of some morphological and productive traits of local bean populations (Phaseolus vulgaris L.). Book of Abstracts of the International Symposium for Agriculture and Food, Skopje, 12-14 December 2012.

Jayasankar S, Babu LC, Sudhakara K, Unnithan VKG. 1999. Provenance Variation in seed and germination characteristics of teak (T. grandis L.) Seed Sci Technol 27: 131-139.

John BA, Gordon RH, Parrish DJ. 1987. Plant Science. McGraw-Hill Publishing Company, New York.

Kebebew F, Tsehaye Y, McNeilly T. 2001. Morphological and farmers cognitive diversity of barley (Hordeum vulgare L. [Poaceae]) at Bale and North Shewa of Ethiopia. Genet Resour Crop Evol 48: 467-481.

Leakey CA. 1988. Genotypic and phenotypic markers in common bean. In: Gepts P. (ed.). Genetic Resources of Phaseolus bean. Kluwer Dordrecht.

Lobo BM, Roberto F, Kami JA, Gepts P. 2010. Microsatellite diversity and genetic structure among common bean (Phaseolus vulgaris L.) landraces in Brazil, a secondary center of diversity. Theor Appl Genet 121: 801-813

Marzooghian A, Valizade M, Moghaddam M, Kooshki MH. 2013. Evaluation of seed storage protein in common bean by same biplot analysis. Intl J Biosci 3: 101-107.

Motlatsi EM, Refiloe P, Lesole S. 2016. Variability in yield and yield components among common bean (Phaseolus vulgaris L.) genotypes. Glob J Agric Res 4 (5): 1-9.

Mouhouche B, Ruget F, Delécolle R, 1998. Effects of water stress applied at different phenological phases on yield components of dwarf bean (Phaseolus vulgaris L.). Agronomie 18: 197-205.

Mudasir S, Sofi PA, Khan MN, Sofi NR, Dar ZA. 2012. Genetic diversity, variability and character association in local common Bean (Phaseolus vulgaris L.) germplasm of Kashmir. Electr J Plant Breed 3 (3): 883-891.

Musango R, Kudzai K, Mhungu S, Tibugar H. 2016. Phenotypic characterization of common bean (Phaseolus vulgaris L.) accessions conserved at the genetic resources and biotechnology institute. J Biodiv Environ Sci 8 (6): 26-36.

Negri V, Tosti N. 2002. Phaseolus genetic diversity maintained on-farm in Central Italy. Genet Resour Crop Evol 49, 511-520.

Newton AC, Akar T, Baresel JP et al. 2009. Cereal landraces for sustainable agriculture. A review. Agron Sustain Dev 30 (1): 237-269.

Njoki NB. 2013. Breeding for durable resistance to angular leaf spot (Pseudocercospora griseola) in common bean (Phaseolus vulgaris) in Kenya [Thesis]. University of KwaZulu-Natal, South Africa.

R Development Core Team. 2011. R: A language and environment for statistical computing. R Foundation for Statistical Computing, 360 Vienna, Austria. URL http: //www.Rproject.org/.

Schut JW, Oi X, Stam P. 1997. Association between relationship measures based on AFLP markers, pedigree data and morphological traits in barley. Theor Appl Genet 95: 1161-1168. 
Sexton PJ, White JW, Boote KJ. 1994. Yield determining processes in relation to cultivar seed size of common bean. Crop Sci 34: 84-91.

Singh SP, Gepts P, Debouck DG. 1991. Races of common bean (Phaseolus vulgaris, Fabaceae). Econ Bot 45: 379-396.

Singh SP. 1999. Improvement of small-seeded race Mesoamerica cultivars. In: Singh SP. (ed.). Common bean Improvement in the Twenty-First Century. Kluwer Academic Publishers. Dordrecht.

Singh SP. 2001. Broadening the genetic basis of common bean cultivars: A Review. Crop Sci 41: 1659-1675.

Sözen Ö, Özçell̆k H, Bozoğlu H. 2014. The revealing of morphological variability and characterization of local bean populations in eastern Black Sea Region. Biyoloji Bilimleri Arastirma Dergisi 7: 29-36

Sperotto RA, Ricachenevsky FK. 2017. Common bean Fe biofortification using model species' lessons. Front Plant Sci 8: 1-6.

Stephen EB, Rao IM, Blair MW, et al. 2013. Phenotyping common beans for adaptation to drought. Front Physiol 4: 35.

Stoilova T, Pereira G, Tavares-De-Sousa M. 2013. Morphological characterization of a small common bean (Phaseolus vulgaris $\mathrm{L}$.) collection under different environments. J Central Eur Agric 14: 1-11
Stoilova T, Pereira G, Tavares-de-Sousa MM, Carnide V. 2005. Diversity in common bean landraces (Phaseolus vulgaris L.) from Bulgaria and Portugal. J Central Eur Agric 6 (4): 443-448.

Svetleva D, Pereira G, Carlier J, Cabrita L, Leitao J, Genchev D. 2006. Molecular characterization of Phaseolus vulgaris L. genotypes included in Bulgarian collection by ISSR and AFLPTM analyses. Sci Hortic 109: 198-206.

Tumsa K, Buruchara R, Beebe SE. 2014. Common Bean Strategies and Seed Roadmaps for Ethiopia. In: Monyo ES, Laxmipathi GCL (eds.) Grain Legumes Strategies and Seed Roadmaps for Selected Countries in Sub Saharan Africa and South Asia, TL-II Project Report, ICRISAT, India.

Villa TC, Maxted N, Scholten MA, et al. 2005. Defining and identifying crop landraces. Plant Genetic Resour 3 (3): 373-384.

White JW, Singh SP, Pino C, Rios BMJ, Buddenhagen I. 1992. Effects of seed size and photoperiod response on crop grown and yield of common bean. Field Crops Res 28: 295-307. 